\title{
Life cycle assessment of a biomass CHP plant in UK: the Heathrow energy centre case
}

Tagliaferri ${ }^{1}$, C., Evangelisti ${ }^{1}$, S., Clift $^{2}$, R., Lettieri ${ }^{1 *}$, P.

${ }^{1}$ Department of Chemical Engineering, University College London, Torrington Place London

WC1E 7JE, UK.

${ }^{2}$ Centre for Environmental Strategy, the University of Surrey, Guildford GU2 7XH Surrey, UK.

*Corresponding author: Email: p.lettieri@ucl.ac.uk

\section{Abstract}

Bioenergy has an important role to play in helping the UK meet its carbon target in 2050 and the European Renewable Energy Directive objectives for 2030. There are however uncertainties associated with the use of bioenergy, and whether or how much it contributes to green-house gas emission reductions. In order to help identifying environmental benefits and burdens associated with biomass use for energy production, an attributional life cycle assessment has been carried out of a biomass-fired CHP plant: the Heathrow Airport energy centre. This facility burns woodchips sourced from nearby forests providing $2 \mathrm{MWe}$ of electricity and $8 \mathrm{MWth}$ of thermal energy which delivers heat and cooling to Heathrow Terminal 2 and low temperature hot water to Terminal 5. A hot spot analysis is conducted to identify the process steps with the largest environmental impact, starting from the harvesting of the forest residue to the disposal of the boiler ash. A scenario analysis is performed to compare the impacts of the biomass plant against fossil alternatives and to identify which renewable energy sources, between biomass and MSW, should be prioritised for development and investment. The results show a reduction in GHG emissions from using biomass, with further benefits if the bottom ash is collected and re-used as a soil conditioner for landfarming or forestry. The paper also discusses the treatment of biogenic carbon in the assessment.

Keywords: biomass fuel; life cycle assessment; CHP; forest residue; biogenic carbon.

\section{Introduction}

The Climate Change Act, which was passed in the UK in 2008, strengthened the UK's commitment to action to tackle climate change under the Kyoto Protocol (CCC, 2015). This act established a framework to develop an economically credible emissions reduction path and set the 2050 targets and carbon budgets. In 2009, the UK Government announced the first carbon budget (Budget 1, 2008-12) which was followed by three updates (Budget 2, 2013-17; Budget 3, 2018-22; Budget 3, 2023-2027) (DECC, 2015). The most recent budget sets a target of $15 \%$ renewable energy by 2020 , across the entire energy spectrum of electricity, heat and 
transport. This implies that around $30 \%$ of the electricity supply (up from current $15.5 \%$ ), $12 \%$ of the heat supply (currently $1 \%$ ) and $10 \%$ of the energy supply for transport will have to be from renewable sources (UK Government, 2009). The UK, as a member of the EU, was a party to even more stringent commitments made during COP21: to reduce emissions of greenhouse gases (GHGs) by at least $40 \%$ relative to 1990 by 2030, going beyond the previous undertaking of $20 \%$ reduction by 2020 (LATVIA AND THE EUROPEAN COMMISSION, 2015).

Although energy consumption is set to increase, renewable sources, including biomass along with wind, hydro and solar, are expected to play an important role in achieving carbonreduction targets. To maximise the potential of biomass to contribute to delivering the policy goals by developing a secure, competitive and affordable supply of fuel, the UK Government has been promoting a major expansion in the supply and use of biomass, as reported in the UK Biomass Strategy and the UK Bio-energy Strategy (DECC, 2012). Biomass supply in the UK is projected to reach approximately 800 TWh by 2030 (including domestic and imported supplies), representing a potential contribution of $10 \%$ to the overall primary energy input (DECC, 2012). Imported biomass will account for part of the supply, so that life cycle cost and environmental assessment of transport is essential. However, there is also significant potential to expand UK domestic supply with no detrimental effect on food supplies or land use if a sustainable approach to woodland management is applied (Kretschmer et al., 2011).

The Heathrow Energy Centre Biomass plant (Heathrow, 2015) is one of the largest biomass initiatives of its kind in the UK. Opened in 2013, the 10 MW CHP plant can provide 2 MWe of electricity and $8 \mathrm{MWth}$ of thermal energy to Heathrow Terminals 2 and 5, helping the airport meet its target of cutting carbon emissions by 34 per cent against 1990 levels (Morgan Sindall, 2015). The biomass plant is fuelled with over 25,000 tonnes per annum of woodchip, currently supplied by LC Energy from sustainable virgin timber sourced within no more than 100 miles from the airport (LC Energy, 2015). The economic driver for the plant is the output of hot water for heating and chilling at terminals but some electrical power is also generated. Because the available temperature is relatively low, an Organic Rankine Cycle (ORC) system is used for power generation.

Although studies on the thermodynamic and economical assessment of Organic Rankine cycle are wide spread in literature (Fergani, Touil, \& Morosuk, 2016; Hassoun \& Dincer, 2015; Lecompte, Huisseune, van den Broek, Vanslambrouck, \& De Paepe, 2015; Yang \& Yeh, 2015), knowledge on the environmental impact of this technology under a life cycle perspective for energy production is still very limited. Some studies address the greenhouse gas reduction of 
the Organic Rankine cycle using solid waste in the far east (Imran, Park, Kim, Lee, \& Usman, 2015; Sedpho, Sampattagul, Chaiyat, \& Gheewala, 2017; Sununta, Sedpho, Gheewala, \& Sampattagul, 2017). However, to the authors' knowledge no studies analysed the entire life cycle of an energy plant based on the ORC using biomass. Hence, this paperpresents a life cycle assessment of the Heathrow plant, from harvesting the wood in the forest, to production of heat and power from the plant, including disposal of the waste. The study is attributional, simply assessing the supply system, because the wood fuel already exists but is otherwise unexploited (see Section 2.1) so that a more complex consequential study is not appropriate. GHG emissions from the plant are compared against generation from fossil fuels using a steam turbine for electricity production. Furthermore, energy production from wood biomass through the ORC is compared to other technologies using renewables, including MSW, to provide insight into the relative advantages of different fuels and associated technologies as a basis for guiding financial investment.

\section{Methodology: Life cycle assessment}

Life Cycle Assessment is one of the most developed and widely used environmental assessment tools for comparing alternative technologies when the location of the activity is already defined (Clift et al., 2000; Clift, 2013). LCA quantifies the amount of materials and energy used and the emissions and waste over the complete supply chain (i.e. life cycles) of goods and services (Bauman and Tillmann, 2004). Moreover, it helps in determining the "hot spots" in the system, i.e. those activities that have the most significant environmental impact and should be improved in the first instance, thus enabling identification of more environmentally sustainable options (Clift, 2006).

In LCA, a multifunctional process is defined as an activity that fulfils more than one function, such as a combined heat and power plant which produce electricity and heat at the same time (Ekvall and Finnveden, 2001). It is then necessary to find a rational basis for allocating the environmental burdens between the functions. The problem of allocation in LCA has been the topic of much debate (e.g. Clift et al., 2000; Heijungs and Guinée, 2007). The ISO standards recommend that the allocation should be avoided by "expanding the product system to include the additional functions related to the co-products" (ISO, 2006a; ISO, 2006b). This can be performed by broadening the system boundaries to include the avoided burdens of conventional productions (i.e substitution by system expansion) (Tillman et al., 1994; Eriksson et al., 2007; ILCD, 2010). The same approach is recommended by the UK product labelling standard provided that it can be proved that the recovered material or energy is actually put 
to the use claimed (BSI, 2011). This approach is applied in this study.

Following the methodological approach of Clift et al. (2000) for Integrated Waste Management (IWM), a pragmatic distinction is made between Foreground and Background, considering the former as 'the set of processes whose selection or mode of operation is affected directly by decisions based on the study' and the latter as 'all other processes which interact with the Foreground, usually by supplying or receiving material or energy'. The burdens evaluated here are considered under three categories (Clift et al., 2000): direct burdens, associated with the use phase of the process/service; indirect burdens, due to upstream and downstream processes (e.g. energy provision for electricity or diesel for transportation); and avoided burdens associated with products or services supplied by the process (e.g. energy produced by the system).

Currently more than thirty software packages exist to perform LCA analysis, with differing scope and capacity: some are specific for certain applications, while others have been directly developed by industrial organisations (Manfredi and Pant, 2011). In this study GaBi 6 has been used (Thinkstep, 2015).

Table 1 shows the impact categories analysed here, they are further described in the supplementary information.

Table 1. Impact categories and indicators analysed in this study.

\begin{tabular}{|c|c|c|c|c|}
\hline Impact categories & Impact Indicator & Acronym & Characterisation model & Units \\
\hline Climate change & $\begin{array}{l}\text { Global warming } \\
\text { potential }\end{array}$ & GWP & $\begin{array}{l}\text { CML } 2001 \text { baseline } \\
\text { (IPCC 2007) }\end{array}$ & $\mathrm{kg} \mathrm{CO}{ }_{2} \mathrm{eq}$ \\
\hline Acidification & $\begin{array}{l}\text { Acidification } \\
\text { potential }\end{array}$ & AP & $\begin{array}{l}\text { CML } 2001 \text { baseline } \\
\text { (Hauschild and. Wenzel, } \\
\text { 1998) }\end{array}$ & $\mathrm{kg} \mathrm{SO}{ }_{2} \mathrm{eq}$ \\
\hline $\begin{array}{l}\text { Resources } \\
\text { depletion (fossil) }\end{array}$ & Abiotic depletion & $A D$ & $\begin{array}{l}\text { CML } 2001 \text { baseline } \\
\text { (Guinée et al., 2001) }\end{array}$ & MJ \\
\hline Eutrophication & $\begin{array}{l}\text { Eutrophication } \\
\text { potential }\end{array}$ & EP & $\begin{array}{l}\text { CML } 2001 \text { baseline } \\
\text { (Hauschild and. Wenzel, } \\
\text { 1998) }\end{array}$ & $\begin{array}{l}\mathrm{kg} \\
\text { phosphate } \\
\text { eq }\end{array}$ \\
\hline $\begin{array}{l}\text { Photochemical } \\
\text { ozone formation }\end{array}$ & $\begin{array}{l}\text { Photochemical } \\
\text { ozone creation } \\
\text { potential }\end{array}$ & POCP & $\begin{array}{l}\text { CML } 2001 \text { baseline } \\
\text { (Jenkin and Hayman, } \\
\text { 1999) }\end{array}$ & $\begin{array}{l}\mathrm{kg} \text { ethane } \\
\text { eq }\end{array}$ \\
\hline
\end{tabular}




\begin{tabular}{|c|c|c|c|c|c|}
\hline \multirow{2}{*}{$\begin{array}{l}\text { Ecotoxicity } \\
\text { (freshwater) }\end{array}$} & \multicolumn{2}{|l|}{ Fresh water aquatic } & USEtox & model & \multirow{2}{*}{$\mathrm{kg} \quad \mathrm{DCB}^{1}$} \\
\hline & $\begin{array}{l}\text { ecotoxicity } \\
\text { potential }\end{array}$ & FAETP & $\begin{array}{l}\text { (Rosenbaum } \\
\text { 2008) }\end{array}$ & et al., & \\
\hline \multirow{3}{*}{$\begin{array}{l}\text { Ecotoxicity } \\
\text { (terrestrial) }\end{array}$} & Terrestric & & USEtox & model & \\
\hline & ecotoxicity & TETP & (Rosenbaum & et al., & kg DCB eq \\
\hline & potential & & 2008) & & \\
\hline \multirow{3}{*}{ Human toxicity } & \multirow{3}{*}{$\begin{array}{l}\text { Human } \\
\text { potential }\end{array}$} & \multirow{3}{*}{ HTP } & USEtox & model & \multirow{3}{*}{ kg DCB eq } \\
\hline & & & (Rosenbaum & et al., & \\
\hline & & & 2008) & & \\
\hline Ozone depletion & $\begin{array}{l}\text { Ozone layer } \\
\text { depletion potential }\end{array}$ & OLDP & $\begin{array}{l}\text { CML } 2001 \\
\text { (WMO, } 2003)\end{array}$ & baseline & $\mathrm{kg} \mathrm{R} 11^{2} \mathrm{eq}$ \\
\hline
\end{tabular}

Note: ${ }^{1}$ DCB: dichlorobenzenes; ${ }^{2}$ R11: trichlorofluoromethane.

\subsection{Forest residues}

This study focuses on forest residues as fuel. The wood chips used at Heathrow are sourced from normal harvesting and maintenance operations in forests within 100 miles from the airport. Biomass forest residue is defined here as the residue gathered during harvesting; it includes annual whole tree thinning, small roundwood, branches and stem tips (Whittaker et al., 2011).

Forest residues are not produced specifically for use as an energy resource. Rather, they are a waste from the production of more valuable forest products, so that harvesting of biowaste for energy recovery does not affect its generation. However, there are other possible environmental implications (Cherubini et al., 2009). The reference scenario for the environmental assessment is current common practice: extraction is not cost-effective so that residues are thinned and left in the forest to decompose along with other debris (Whittaker et al., 2011). This can have a significant role in sequestering carbon in soil, dead wood and leaf litter, and also in restoring soil nutrients, whilst also improving the habitat and hence the biodiversity of the forest (DEFRA, 2008; Cherubini et al., 2009; Whittaker et al., 2011). Harvesting the residues has a direct effect in reducing these beneficial effects but the environmental consequences are difficult to quantify. Changes in carbon flux are particularly complicated because the potential to sequester carbon in the soil is dependent on former and current agronomic practices, climate and soil characteristics and is therefore site-specific. Furthermore, the timescale for decomposition of forest residues is many orders of magnitude 
greater than the timescale over which they are used as fuel. Therefore as recommended by Whittaker et al. (2011), the assessment does not include the background effects on forests of extracting the residues.

At the level of consequential effects, creation of a market for forestry wood waste can make the production of the main forest products more attractive, leading to an expansion of forest land to displace other land uses. This may have negative or positive environmental impacts, depending on the activities replaced. However, the consequences are even more uncertain, and differ between different scenarios. They are therefore not included in this assessment.

Two different forest tree species are considered in this study: a Sitka spruce forest, which is representative for a softwood species and a poplar forest, which represents a hardwood species.

\subsection{Biogenic carbon}

Biogenic $\mathrm{CO}_{2}$ emissions are defined as 'emissions from a stationary source directly resulting from the combustion or decomposition of biologically-based materials other than fossil fuels' (US EPA, 2011). In this study, following the approach of Christensen et al. (2009) and Manfredi et al. (2011), the $\mathrm{CO}_{2}$ emitted from combustion of biomass at the Heathrow energy centre is considered neutral with respect to global warming because the sequestration of $\mathrm{CO}_{2}$ during forest regrowth offsets the emissions from burning the biomass. In effect, it is assumed that the biomass is sustainably harvested so that forest is considered to be at steady state with no changes to the carbon stock (Guest et al., 2013). This conforms with general practice followed when considering emissions due to biomass burning, and is in agreement with the guidelines of the Organization for Economic Cooperation and Development (OECD, 1991) for estimating national GHG emissions and sinks (OECD, 1991). The simplification is supported by the work of Cherubini et al. (2011): the emission factor for the CO2 emitted by burning forest residues integrated over the 20/100/500-year is negligible because the rotation period (i.e. the thinning cycle) for this kind of feedstock is usually less than 10 years (Kerr and Haufe, 2011).

\subsection{Goal and Scope definition}

Figure 1 shows the system considered in this paper. The overall aim of the study is to assess the environmental impacts associated with production of heat and power from forest residues, to identify the environmental "hot spots" in the system and to compare it with alternative energy systems. The specific goals are therefore to:

1) Evaluate the environmental impacts of the Heathrow energy centre biomass plant, 
through an attributional life cycle assessment;

2) Analyse individual plant operations through a hot spot analysis;

3) Conduct a comparative analysis considering different forest species and different devices for energy production, such as ORC and steam turbine, as summarized in Table 1.

4) Compare the carbon footprint of electricity production from forest residues against fossil sources and technologies and expand the analysis to also include other renewable feedstocks. Hence, the following options are considered (see Table 2): a combined cycle natural gas plant; a coal plant; the current UK electricity grid mix and the projected 2030 grid mix; and incineration of MSW.

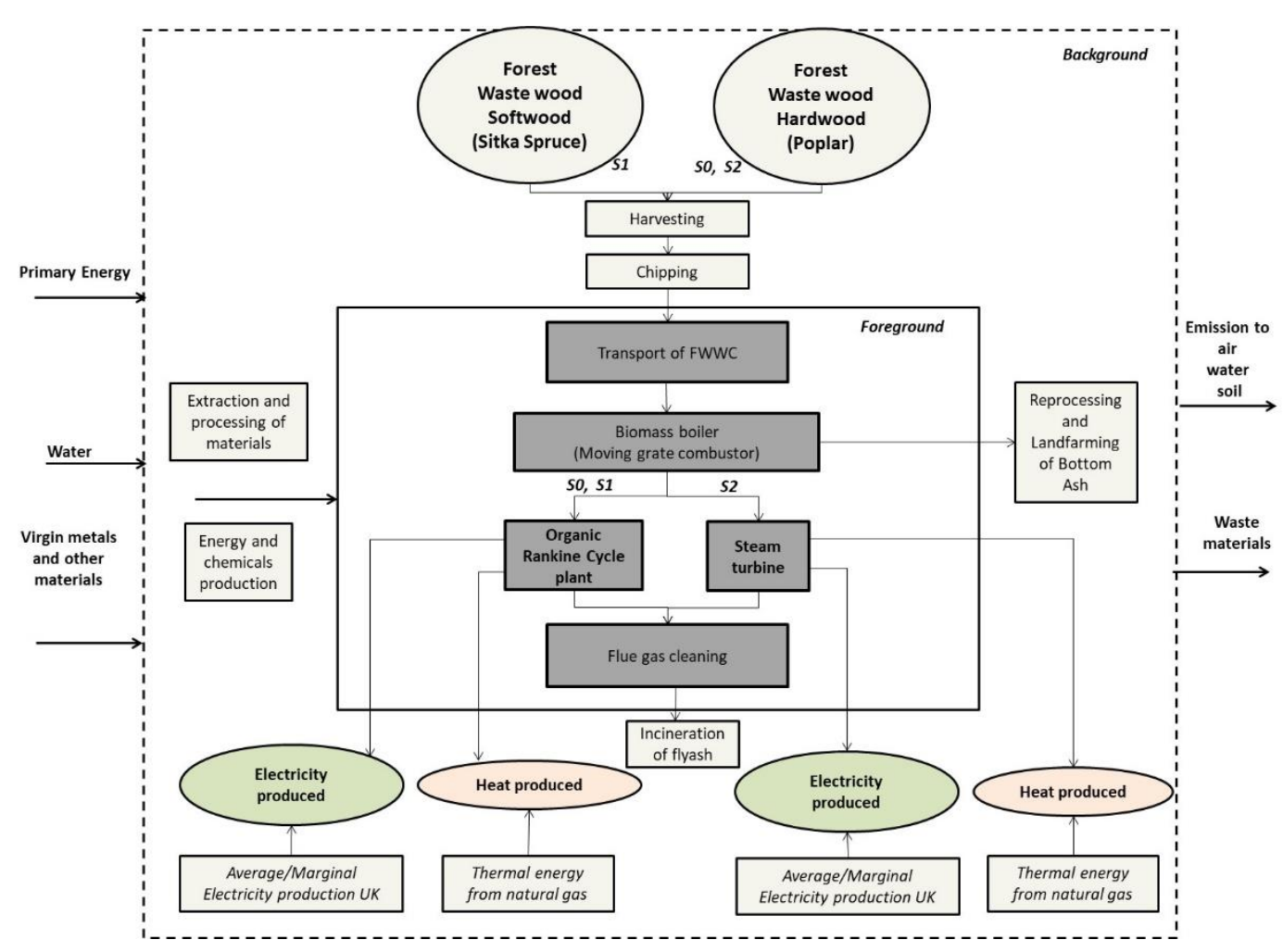

Figure 1. System boundaries. FWWC: forest waste wood chips.

Table 2. Scenario description.

\begin{tabular}{|l|l|l|}
\hline Scenario & Description & Wood density \\
\hline S.0 & $\begin{array}{l}\text { Baseline scenario for the Heathrow energy centre: } \\
\text { thinned and chopped hardwood (i.e. Poplar) from }\end{array}$ & $\begin{array}{l}239 \mathrm{~kg} / \mathrm{m} 3 \mathrm{dried} \\
\text { matter }\end{array}$ \\
\hline
\end{tabular}




\begin{tabular}{|l|l|l|}
\hline & $\begin{array}{l}\text { the forest is transported to the Heathrow } \\
\text { combustion and ORC plant to produce electricity } \\
\text { and thermal energy. }\end{array}$ & \\
\hline S.1 & $\begin{array}{l}\text { Softwood (i.e. Sitka spruce) is used rather than } \\
\text { hardwood in the Heathrow plant. }\end{array}$ & $\begin{array}{l}169 \mathrm{~kg} / \mathrm{m} 3 \mathrm{dried} \\
\text { matter. }\end{array}$ \\
\hline S.2 & $\begin{array}{l}\text { Hardwood forest residues are used to produce } \\
\text { energy in a biomass boiler followed by a steam } \\
\text { turbine }\end{array}$ & $\begin{array}{l}239 \mathrm{~kg} / \mathrm{m} 3 \text { dried } \\
\text { matter }\end{array}$ \\
\hline S.3 & $\begin{array}{l}\text { Electricity is produced by incineration of municipal } \\
\text { solid waste. The LCA model is based on the North } \\
\text { Hykeham incineration plant in the UK (Evangelisti } \\
\text { et al., 2015) with landfilling as the reference } \\
\text { system replaced }{ }^{1} .\end{array}$ & \\
\hline S.4 & $\begin{array}{l}\text { Electricity is produced using hard coal, based on } \\
\text { published data (Thinkstep, 2015). }\end{array}$ & \\
\hline S.5 & $\begin{array}{l}\text { Electricity is produced using natural gas according } \\
\text { to Thinkstep (2015) } \\
\text { The UK electricity mix is considered according to } \\
\text { Thinkstep (2015). }\end{array}$ & \\
\hline grid, 2014) & \\
\hline
\end{tabular}

Note: ${ }^{1}$ In the reference scenario MSW is considered to be sent to an engineered landfill, where biogas produced by the landfill is partially used to produce electricity (Thinkstep, 2015).

The functional unit chosen for this study is $1 \mathrm{MWh}$ of electrical output. The thermal energy also produced is treated as a co-product and included in the assessment through the avoided burdens corresponding to a conventional production system: a condensing boiler fired with natural gas.

The forest growth is not included in this analysis as also reported in Sections $2.1 \&$ 2.2. The life cycle of energy production from forest residues includes the following steps: harvesting, chipping, transportation of the forest waste wood chips (FWWC) to the CHP facility, electricity production in the combustion and ORC plant, reprocessing of the bottom ash to be used for 
land-farming activities and disposal of the fly-ash through incineration (see Figure 1). No avoided burdens for bottom ash land-farming are considered, given that there are still uncertainties about the real amount of bottom ash which can be used as fertilizer. This is a limitation of this study.

\section{Life cycle inventory}

In this paragraph, the different steps analysed in Figure 1 are described.

\subsection{Harvesting and wood chips production}

Harvesting operations include the thinning and final cut of wood, which is accounted for in the model according to the Ecoinvent 2.1 database (Swiss Centre for Life Cycle inventories, 2011). All energy and materials requirements for harvesting, including the power for sawing and materials for machines building are also considered in the LCA model according to the Ecoinvent 2.1 database (Swiss Centre for Life Cycle inventories, 2011). These depend on the bulk density of the forest residue, which is different for S.0 and S.1 scenarios as shown in Table

2. Chipping is assumed to be done at the forest using a mobile chopper, with a diesel consumption of $33.7 \mathrm{MJ}$ and $23.8 \mathrm{MJ}$ of diesel for $1 \mathrm{~m}^{3}$ of dry wood, for hardwood and softwood respectively (Swiss Centre for Life Cycle inventories, 2011).

\subsection{Wood chips transportation}

The wood chips are assumed to be transported 100 miles before reaching the processing plants. This is because the wood supplier of the Heathrow energy centre (i.e. LE Energy) ensures a maximum 100 miles distance from the sourcing point to the plant (LC Energy, 2015). A medium size truck Euro 5 with 12-14 t gross weight and 9.3 t payload with the associated diesel consumption have been considered according to Thinkstep dataset (2015).

\subsection{Biomass boiler}

The wood chip ultimate analysis is reported in Table 3 according to the Ecoinvent 2.1 database (Swiss Centre for Life Cycle inventories, 2011). The emissions due to the storage of FWWC at the Heathrow energy centre plant are not included in the assessment because the loading of wood at the plant is done continuously during the day to avoid long storage period (4-5 lorry per day) (Heathrow Energy centre, 2014). According to the data collected at the Heathrow energy centre (Heathrow Energy centre, 2014) a system of moving floors conveys the fresh wood chips in the combustion chamber operating at $950{ }^{\circ} \mathrm{C}$; the biomass is converted in flue gas through a moving grate combustor rating $11.4 \mathrm{MWth}$.

Table 3. Ultimate analysis of the wood chip used at the Heathrow energy centre biomass plant 
(Heathrow energy centre, 2014).

\begin{tabular}{|l|l|}
\hline Ultimate analysis & Values \\
\hline Wood chip moisture content & $40-60 \%$ \\
\hline Wood chip net calorific value [on total mass value] & $10.3 \mathrm{MJ} / \mathrm{kg}$ \\
\hline $\mathrm{C}$ & $47.9 \%$ dry basis \\
\hline H & $5.18 \%$ dry basis \\
\hline O & $44.6 \%$ dry basis \\
\hline S & $0.02 \%$ dry basis \\
\hline N & $<0.3 \%$ dry basis \\
\hline Ash & $2.0 \%$ dry basis \\
\hline
\end{tabular}

The plant has a wood chip throughput of 100t/d (Heathrow Energy centre, 2014) and it is assumed that the plant operates for 7000 h/y (Swiss Centre for Life Cycle inventories, 2011). The parasitic loads of the biomass boilers are included in the inventory according to the Ecoinvent 2.1 database (Swiss Centre for Life Cycle inventories, 2011), which reports an electricity consumption equivalent to $1.5 \%$ of the fuel energy content.

According to the data collected at the Heathrow energy centre (Heathrow Energy centre, 2014) the thermal energy of the flue gas which is produced in the combustion chamber is then recovered in a heat exchanger by an organic thermal oil-Therminol $66\left(6.2 * 10^{-5} \mathrm{~kg}\right.$ per $\mathrm{kg}$ of wood chip). This is a clear, pale, yellow liquid consisting of modified terphenyl with a density of $1005 \mathrm{~kg} / \mathrm{m}^{3}$ and a molecular weight of $252 \mathrm{~g} / \mathrm{mol}$ (Eastman, 2015b).

The organic oil life time is assumed to be 10 years (Heathrow energy centre, 2015); hence, one change of the organic thermal oil is considered during the entire plant life of 20 years. A limitation is that no dataset was available for Theminol 66 oil production. However, benzene production from pyrolysis gasoline is based on a similar process (Eastman, 2015a), hence in this study it is considered as a proxy for the organic Therminol oil 66 production. To account for the difference in molecular weight between the organic oil and benzene, the production of $5.8 * 10^{-5} \mathrm{~kg}$ of benzene per $\mathrm{kg}$ of wood chip treated is included in the LCA inventory (Thinkstep, 2015). Bottom ash is assumed to be produced in the boiler. The mass of the bottom ash is estimated to be $0.4 \%$ of the total input fuel mass (Heathrow Energy centre, 2014). Bottom ash from boilers is disposed as wood incineration ash in land farming according to Ecoinvent , 2.1 (Swiss Centre for Life Cycle inventories, 2011). 


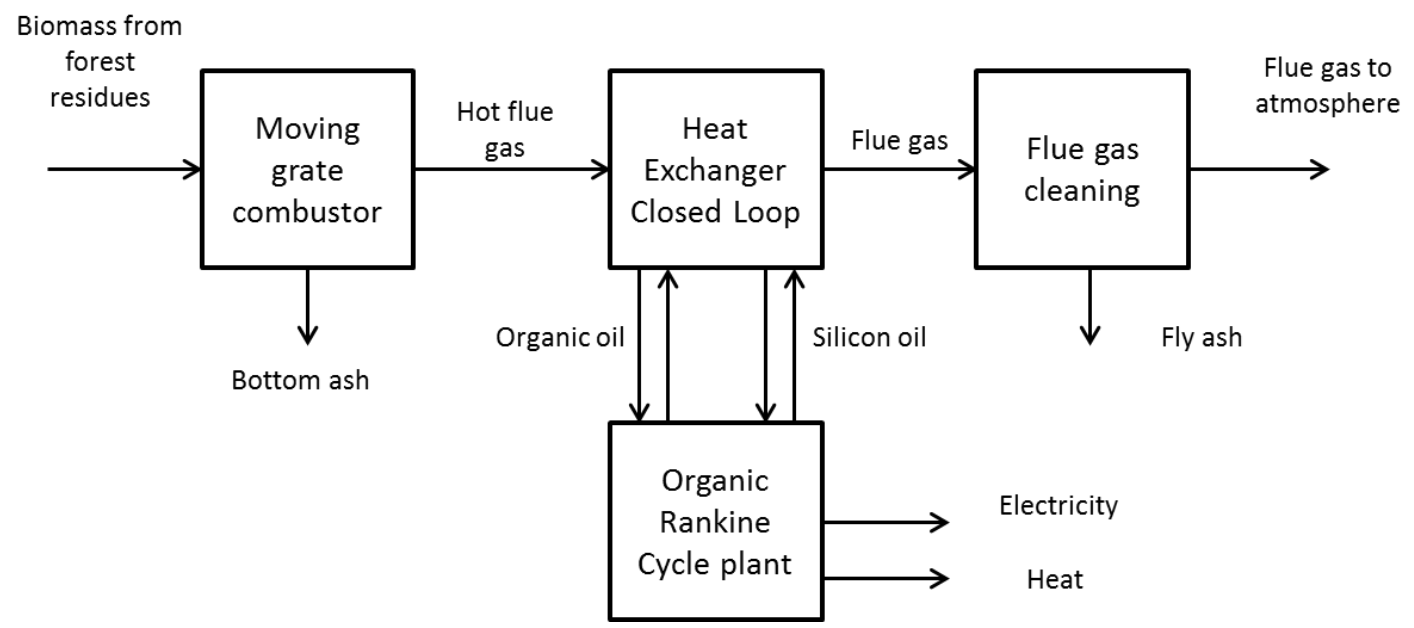

Figure 2. High level process diagram of the Heathrow energy centre biomass plant

\subsection{ORC and energy recovery}

According to the information collected at the Heathrow energy centre (Heathrow Energy centre, 2014), the energy content received by the thermal oil is then transferred to the silicon oil of the ORC cycle to produce energy; the oil and the ORC are both supplied by Turboden (Obernberger, Thonhofer, \& Reisenhofer, 2002). The ORC model TURBODEN 18 CHP Split (Turboden, 2015) is installed in the Heathrow energy centre biomass plant and its parasitic loads are $87 \mathrm{kWe}$ (Turboden, 2104).

The silicon oil is a (organic) high molecular mass fluid with a lower boiling point temperature compared with water, which allows a Rankine cycle to recover heat from lower temperature sources, such as biomass combustion. The silicon oil in the liquid form is fed into the ORC system through a pump and it undergoes initial heating in the regenerator coil. Then, it is conveyed to the pre-heater and into the evaporator; here the organic oil coming from the combustion chamber increases the Silicon oil temperature until its evaporation point. The vapour generated expands into the turbine to produce electricity. Downstream of the turbine the vapour contributes to pre-heat the fluid in the regenerator.

The plant produces both heat and power to be delivered to the buildings of Terminal 2 and 5 of Heathrow airport. In particular, when working at full capacity, the net electricity output is 2 MWe and the net thermal output, including also additional heat recovered from the cleaning section of the flue gas is $8 \mathrm{MWth}$ (Heathrow Energy centre, 2014). The calculated net electrical and thermal efficiencies based on a biomass net calorific value of $10.3 \mathrm{MJ} / \mathrm{kg}$ are $16 \%$ and $64 \%$, respectively. The heat is delivered as hot water to the terminal buildings at $95{ }^{\circ} \mathrm{C}$ (Heathrow Energy centre, 2014). 
No data were available on the amount of the Silicon oil used in the ORC cycle. However, it is assumed that the life time of the oil is at least 10 years; hence, given a plant life time of 20 years, the use of oil allocated to $1 \mathrm{MWh}$ of electricity produced is considered negligible.

\subsection{Steam turbine}

Scenario S.2 assumes that the ORC system is substituted by a steam turbine. In this scenario, the thermal energy content of the thermal oil is used to produce steam which is then used to run the steam turbine according to literature data (Evangelisti et al., 2015).

\subsection{Gas cleaning and emissions to environment}

Once the energy content of the flue gas produced in the biomass boiler is removed in the heat exchanger by the thermal oil, the exhausted gas undergoes several cleaning stages. It then goes through an economiser for further recovery of heat; and a condenser. The parasitic loads for the gas cleaning (i.e. electrostatic precipitator for particle removal) is considered according to the value reported in Saiyasitpanich et al. (2007). The gases are than emitted to the atmosphere from the stack. The mass of the fly ash produced from the cleaning section is estimated to be $0.4 \%$ of the total input fuel mass (Heathrow Energy centre, 2014). Fly ash is treated in an incineration plant according to the Ecoinvent database.

For the emissions at the stack, the emissions limits for boilers with nominal heat output less than 20MWth are here considered as reported in the literature (Amec, 2013).

\subsection{Incineration of municipal solid waste}

The municipal solid waste considered for the waste-to-energy plant ( $\mathrm{S} .3$ scenario) has a typical UK composition, as also reported in Evangelisti et al. (2015). The waste is considered to be transported from the transfer station to the incineration plant for 100 miles (Evangelisti et al., 2014). The incineration model is based on a designed plant in UK, located in North Heykenham. The inventory for this scenario is based on Evangelist et al. (2015).

\section{Impact Assessment results}

In the Impact Assessment phase, the emissions and inputs quantified in the Inventory phase are translated into a smaller number of impacts. The study focusses on six impact categories which are found to be most significant for the analysis of the Heathrow energy centre biomass plant, as shown in the normalized results presented in the Supplementary Information. 


\subsection{Heathrow energy centre biomass plant: Hot spot analysis}

Table 4 shows the results for the attributional LCA of the Heathrow energy centre biomass plant, for the hardwood forest residue (scenario S.0) and for the softwood forest residue (scenario S.1), per MWhe of electricity produced. Credits for the avoided burdens due to heat production from the plant are accounted considering an average technology (i.e. natural gas boiler). No credits are accounted for electricity production because a comparison with other electricity production scenarios is presented in Section 4.3 (in any case the avoided burdens for electricity production allocated to all scenarios would have been the same as the results are calculated for $1 \mathrm{MWh}$ of production).

In general, the impact categories of the fossil resource depletion (Abiotic Depletion Potential) and global warming potential are negative for the Heathrow energy centre biomass plant, compared with the current UK mix of technologies for heat production, bringing savings in terms of GHG emissions and fossil fuels. However other categories show a positive environmental impact.

Table 4. Results of the LCA of the Heathrow energy centre biomass plant. Scenario S.0 and S.1. Functional unit: $1 \mathrm{MWhe}$ produced by the plant.

\begin{tabular}{lcc}
\hline Impact Indicator & $\begin{array}{c}\text { S.O (Baseline) } \\
\text { Harwood - ORC }\end{array}$ & $\begin{array}{c}\text { S.1 } \\
\text { Softwood - ORC }\end{array}$ \\
\hline Abiotic Depletion (MJ) & $-1.19 \mathrm{E}+04$ & $-1.11 \mathrm{E}+04$ \\
\hline Acidification Potential (kg SO2eq) & $1.53 \mathrm{E}+00$ & $1.91 \mathrm{E}+00$ \\
\hline Eutrophication Potential (kg Phosphate eq) & $5.05 \mathrm{E}-01$ & $6.25 \mathrm{E}-01$ \\
\hline Freshwater Aquatic Ecotoxicity Pot. (kg DCB eq) & $1.04 \mathrm{E}+01$ & $1.85 \mathrm{E}+01$ \\
\hline Global Warming Potential (kg CO2eq.) & $-6.85 \mathrm{E}+02$ & $-6.30 \mathrm{E}+02$ \\
\hline Human Toxicity Potential (kg DCB eq) & $6.28 \mathrm{E}+01$ & $1.11 \mathrm{E}+02$ \\
\hline Ozone Layer Depletion Potential (kg R11 eq) & $4.68 \mathrm{E}-06$ & $1.17 \mathrm{E}-05$ \\
\hline Photochem. Ozone Creation Potential (kg Ethene eq) & $4.25 \mathrm{E}-01$ & $8.18 \mathrm{E}-01$ \\
\hline Terrestric Ecotoxicity Potential (kg DCB eq) & $1.05 \mathrm{E}+01$ & $1.09 \mathrm{E}+01$ \\
\hline
\end{tabular}

For all the impact categories analysed, the use of hardwood forest residue, such as Sitka spruce, as a feedstock for the plant, shows a reduced environmental impact compared with a softwood forest residue, such as Poplar. This is because the bulk density of softwood residue (169 kg/m3 dry matter) is about 30\% smaller than the hardwood residue density (239 $\mathrm{kg} / \mathrm{m} 3$ dry matter), hence affecting the amount of soft or hardwood needed to produce the 
same amount of energy. The production of $1 \mathrm{MWh}$ of electricity requires $1840 \mathrm{~kg}$ of woodchips, corresponding to $7.9 \mathrm{~m}^{3}\left(1.335 \mathrm{ODT}^{1}\right)$ of softwood, compared to $3.8 \mathrm{~m}^{3}$ (0.908 ODT) of hardwood required. This in turn determines higher energy requirements in terms of diesel for the thinning and final cutting operations. As shown in Figure 3, the chopping of the forest wood determines a lower impact compared to thinning and final cutting operations for all impact categories and it is similar for the two forest species analysed.

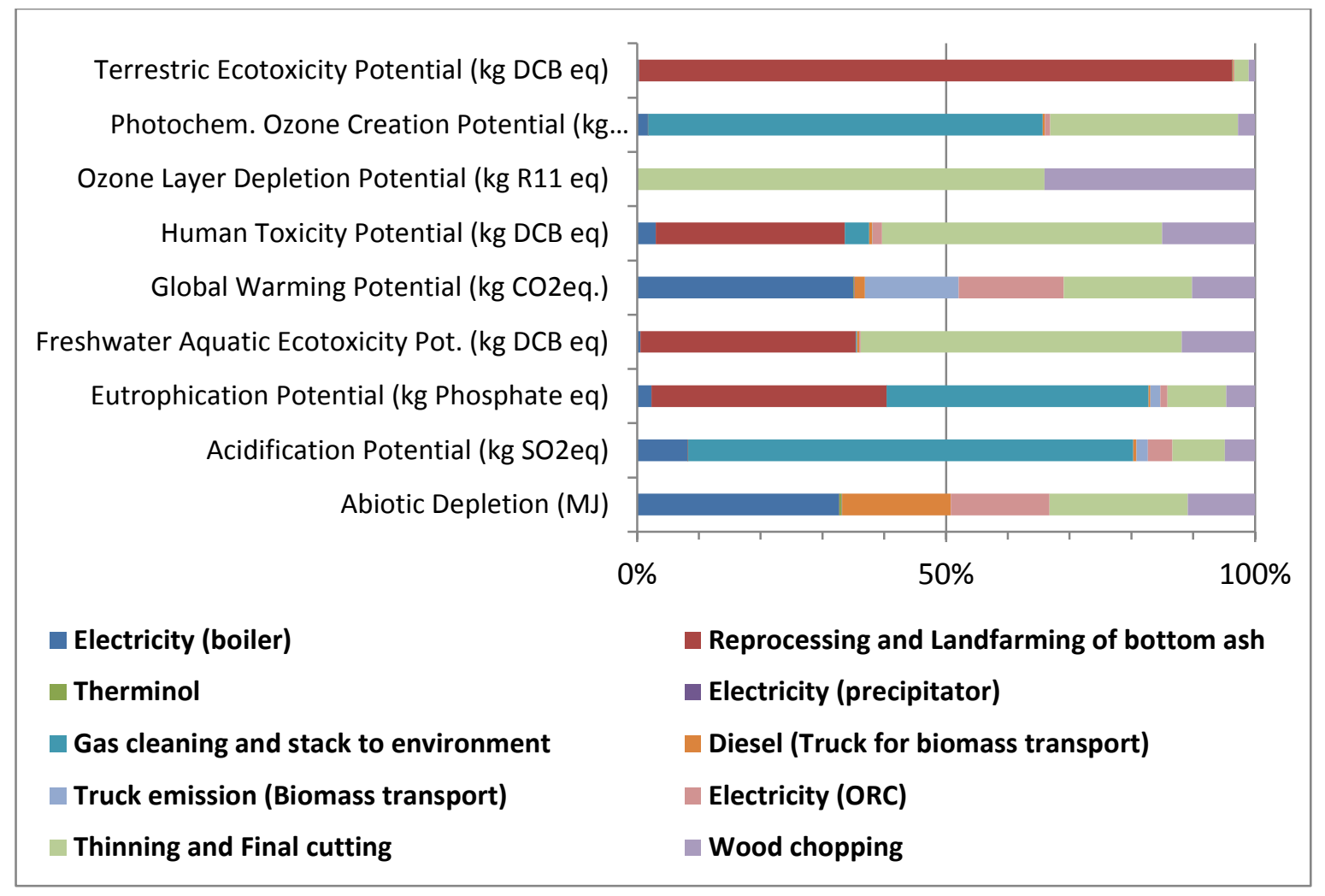

Figure 3. Hot spot analysis of the environmental impacts of the Heathrow energy centre biomass plant for Scenario S.O (baseline).

In terms of fossil resource depletion, the parasitic consumption of the boiler produces the highest impact (more than $30 \%$ of the total), followed by the harvesting and chipping operations (wood chopping, thinning and final cutting) which accounts for another $30 \%$, due to the diesel consumed by the equipment used. This is also confirmed in the study by Whittaker et al. (2011) which reported harvesting and chipping as being the most significant process steps in terms of energy use and GHG emissions. Transportation results in a $18 \%$ impact for the abiotic depletion indicator: this is expected to become more relevant if the 100 miles distance between the plant and the forest increases.

The acidification category is dominated by the direct emissions from the biomass plant (more

${ }^{1}$ ODT: Oven dry tonne. 
than $75 \%$ of the total AP) and this due to the assumption that the SOx emissions equal the emission limits for boilers.

The reprocessing and spreading on the land of the bottom ash produced by the biomass boiler has a relevant impact in the eutrophication (40\%) and ecotoxicity category referred to fresh water (35\%), human (30\%) and terrestrial ecotoxicity. For the latter, the reprocessing of the bottom ash is responsible for more than $90 \%$ of the total impact. In this study, no avoided burdens have been accounted for in the use of wood ash as a substitution for chemical fertilisers.

The GHG emissions associated with the biomass plant are mainly due to the parasitic load of the plant (50\%); transportation of the wood chips (20\%); and harvesting and wood chips preparation (30\%).

For the human toxicity category, the highest impact is determined by the harvesting and chipping operations, which accounts for more than $60 \%$ of the total. This is mainly due to the direct emissions associated with the use of diesel in harvesting machines and mobile choppers, which do not usually have catalytic converters to reduce the emissions.

\subsection{Steam turbine as prime mover for the biomass plant}

In scenario S.2, a steam turbine is assumed to substitute the ORC system. Figure 4 presents the results obtained for the steam turbine, normalised to the impacts of Scenario S.0. For all the impact categories analysed, the steam turbine scenario shows a higher impact compared with the baseline. The lower electric efficiency of the steam turbine, determines a higher consumption of fresh hardwood for the production of $1 \mathrm{MWh}$ of electricity- in this case, up to $2280 \mathrm{~kg}$ of wood are required instead of $1840 \mathrm{~kg}$ supplied to the ORC baseline scenario.

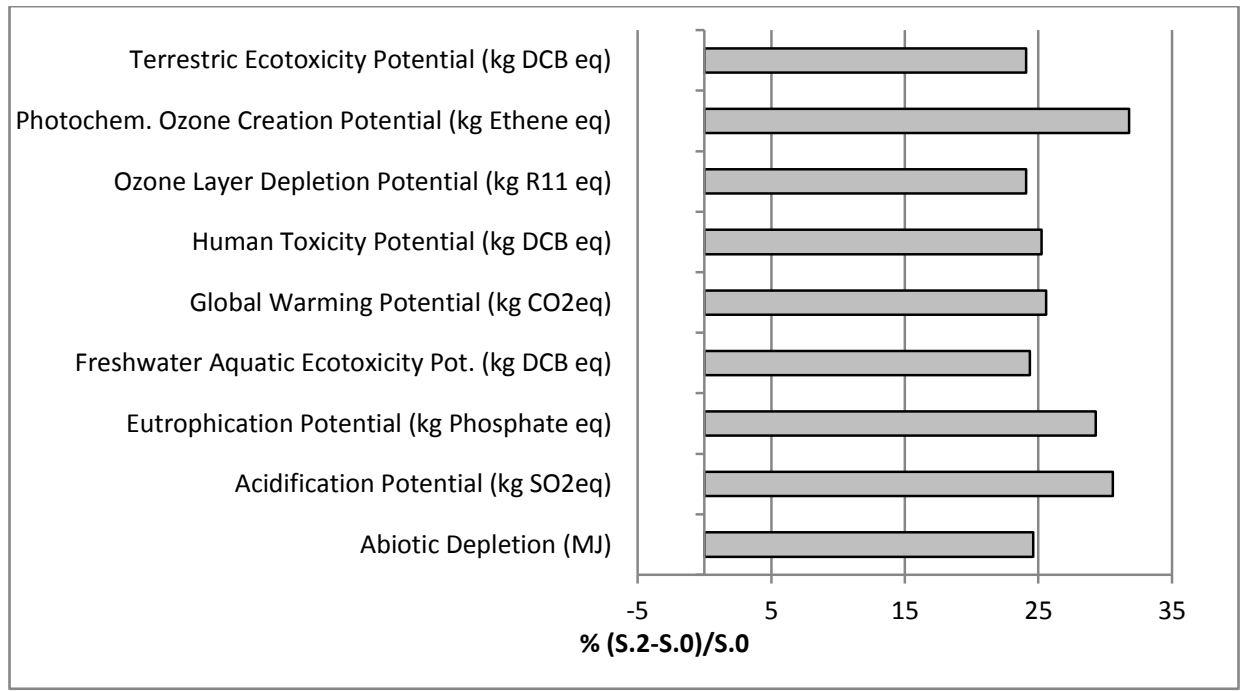

Figure 4. Environmental impact of Scenario S.2 (Steam turbine) compared to the baseline (S.0). 


\subsection{Alternative scenarios for electricity production}

\subsubsection{Comparison with fossil alternatives}

In this paragraph, the biomass plant for power production (S.0) is compared to fossil alternatives to identify the greenhouse gas gain of renewable sources over conventional fossil processes for power production.

The two fossil fuels scenarios included are a coal power plant and a natural gas power plant; these represent the marginal electricity production technologies for the UK electrical market (Evangelisti et al., 2014) and together, they supply the $70 \%$ of the current electricity demand in the UK (Thinkstep, 2015). Furthermore, two scenarios for the UK average electricity mix are considered: one representing the current mix (2015) and the other being a 2030 scenario developed by National Grid for the UK electricity market in the future (National grid, 2014). Figure 5 shows the results of the comparison of the baseline scenario, representing the Heathrow energy centre biomass plant, against the fossil alternatives, when $1 \mathrm{MWh}$ of electricity is produced. The scenario referred to the baseline shows a lower GWP and AD impact compared with fossil power plants and with the current and future UK energy mix. The lower GWP of the renewable energy source is due to its biogenic carbon content that is accounted as zero $\mathrm{CO}_{2}$ emissions from combustion as previously explained.

This is opposite in the human toxicity, ozone depletion and photochemical formation impact categories because of the higher emissions associated with wood chipping, ash disposal and chemical use of electricity production from biomass.

For AP, the natural gas plant is the best option, because of the low nitrogen content in the gas; conversely the coal plant is shown to be the worst option as widely reported in literature.

Finally, Figure 5 shows how the predicted energy mix of 2030 determines a lower environmental burdens than the 2015 electricity mix thanks to an increased share of renewables and nuclear in the next future. 

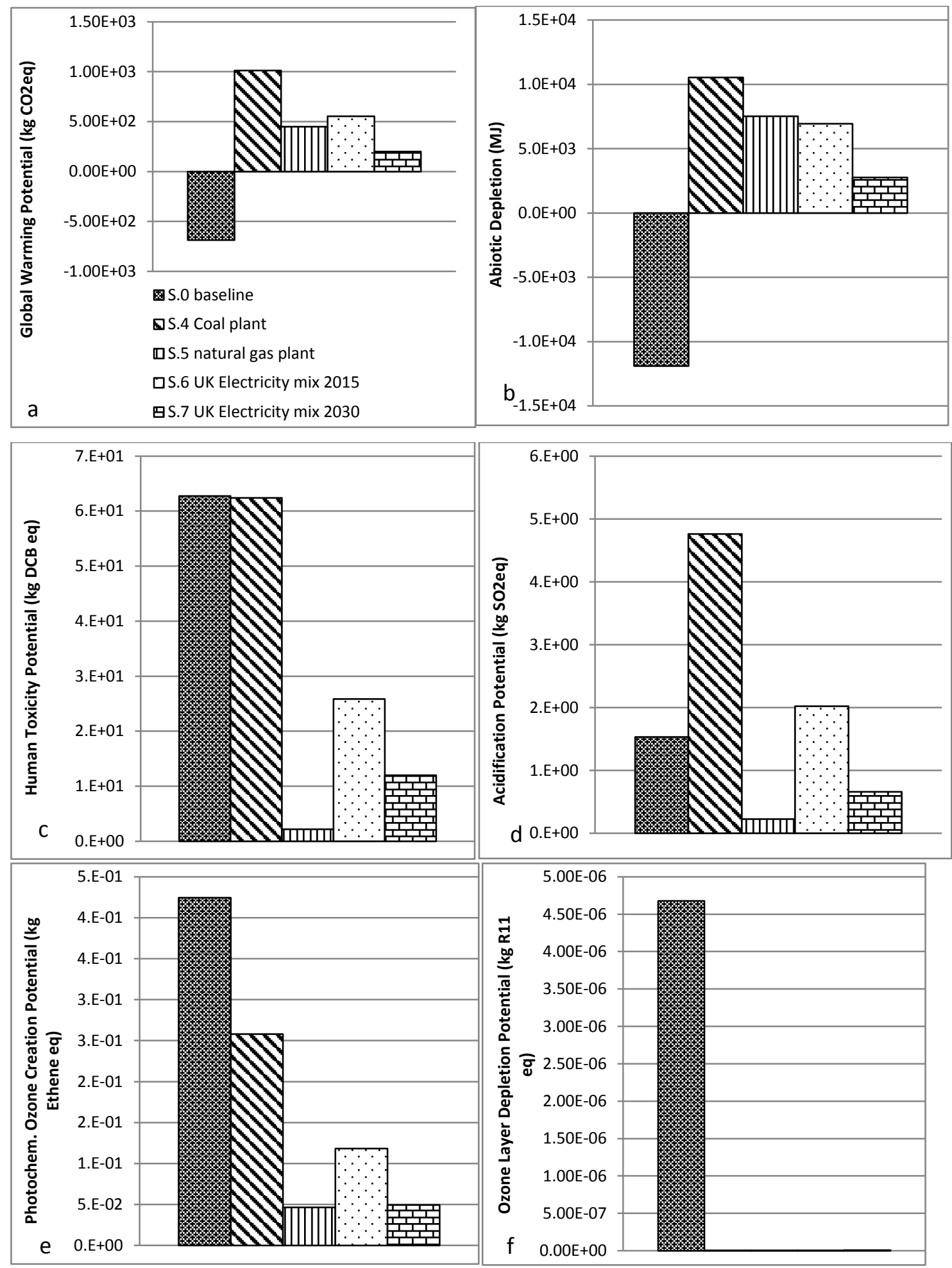

Figure 5. Environmental impacts comparison amongst alternative scenarios for electricity production. A) GWP, b) AD, c) HTP, d) AP, e)POCP, and f) ODP.

\subsubsection{Comparison with alternative renewable technologies}

The electricity production from wood biomass through the ORC cycle is also compared to other technologies processing renewables, such as electricity production from MSW. The latter does 
not have to be considered as a competing alternative to wood biomass use as both feedstocks contribute to meet the renewable targets. However, this type of comparison identifies which are the preferred renewable feedstocks and associated technologies to be financially sustained as a first option in case of availability of public investment.

Scenario S.3 is referred to a MSW incineration plant for electricity - only production, which is assumed to avoid the landfilling of the same amount of MSW (reference scenario).
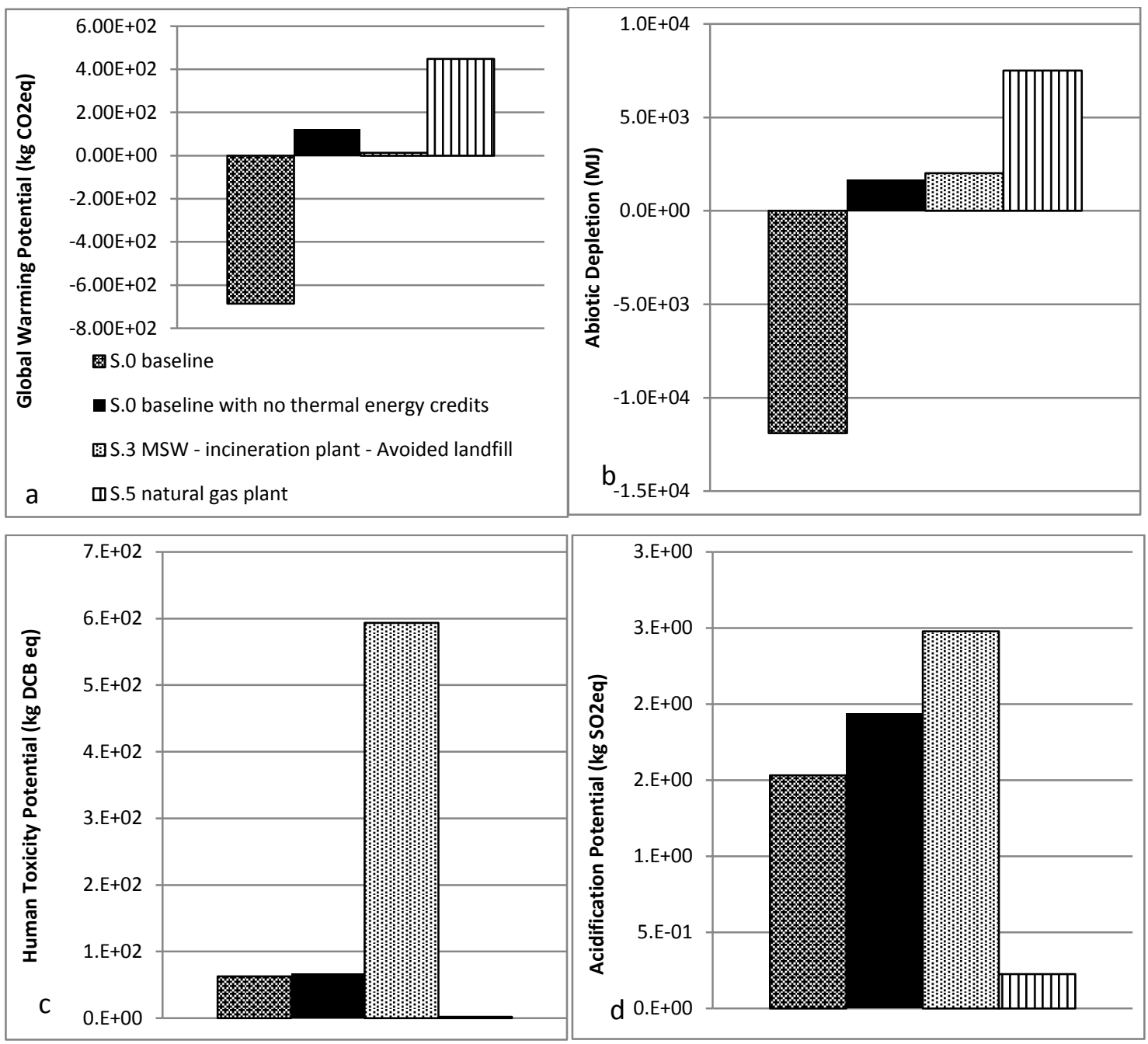


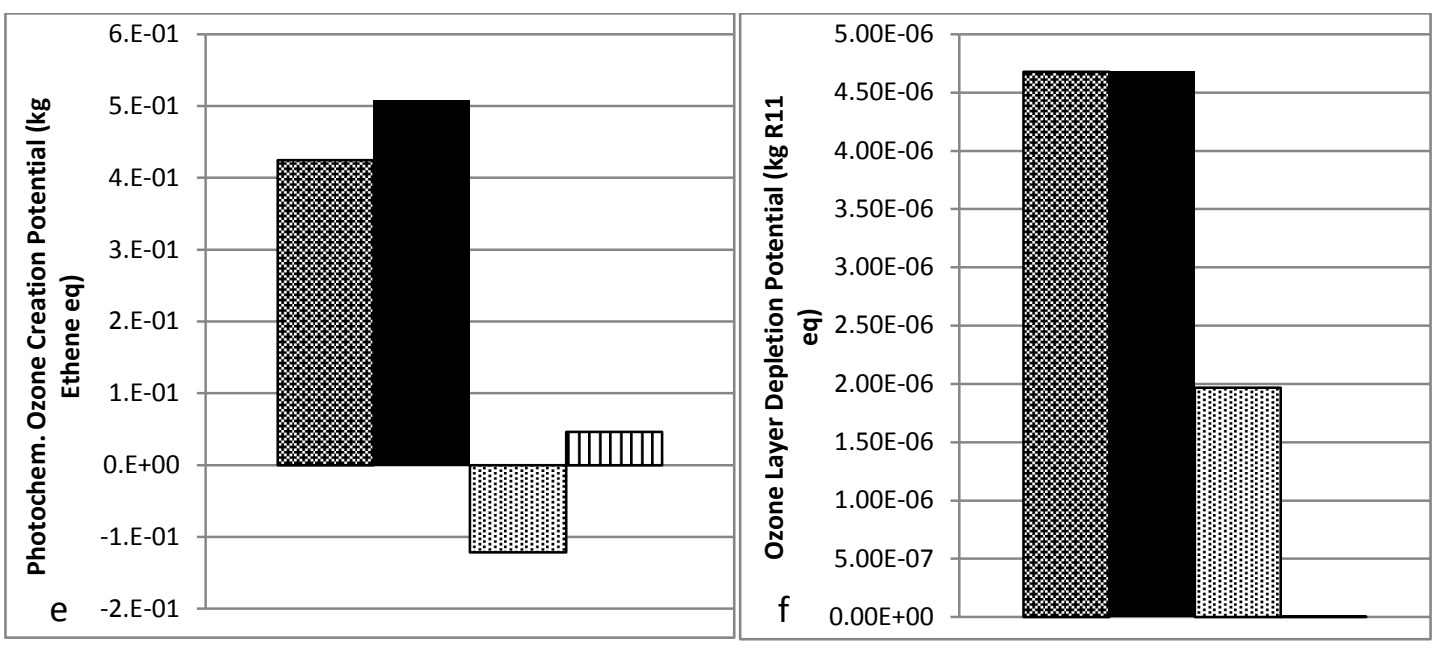

Figure 6. Environmental impacts comparison amongst alternative scenario for electricity production. A) GWP, b) AD, c) HTP, d) AP, e)POCP, and f) ODP.

Figure 6 shows the results of the comparison of the baseline scenario against the other renewable technology and the best fossil technology for production of electricity, when 1 MWh of electricity is produced. For a fair comparison with the MSW incineration plant, a baseline scenario not accounting for the environmental credits due to the thermal energy produced along by the electricity is shown as well. The Heathrow biomass plant results the most environmentally friendly option for the climate change category. If compared with the waste-to-energy scenario (S.3), the Heathrow biomass plant allows almost a saving of $700 \mathrm{~kg}$ of CO2eq per MWh produced. However, when no thermal credits are included in the baseline scenario, the GWP impact turns slightly higher compared with the waste-to-energy plant. This is mainly due to the fact that $\mathrm{S} .3$ benefits for the environmental credits related to the avoided landfilling of the MSW, which is then diverted for power production in the incineration plant. This study is based on the UK context; a considerable amount of MSW ( 30\% in 2013) is still treated in landfill (DEFRA, 2014). The results could be different for countries with a different waste management scenario, where the potential reference system for the treatment of MSW could be 'greener' compared to landfill.

The production of electricity using biomass (S.0) and MSW (S.3) are not opposing processes but both need to be considered when tackling the renewable energy challenge. However, as in the UK the MSW disposal to landfill is still a widely used option, financial and technological investments for the development of new generation incinerations, determine a higher reduction of GHG compared to biomass use for electricity production. The different environmental impacts are due to the reference systems of the two cases, the landfill option 
for the incineration and the wood left in the forest for the wood biomass used in a boiler.

The results are opposite for the abiotic depletion, human toxicity and acidification potential indicators, where the waste-to-energy scenario shows a higher impact compared to the baseline. For the photochemical ozone creation potential and for the ozone layer depletion potential indicators, instead, the incineration of MSW is the best option for power production, compared with the biomass plant. The avoiding of MSW landfilling results in a negative effect of scenario S.3 in the former indicators, while the baseline scenario performed worse. This is mainly due to the direct emissions to the atmosphere in the harvesting and chipping phases.

\subsection{Discussion}

The hot spot analysis of the Heathrow energy centre biomass plant helps determining the process steps, which show the highest impact in the categories analysed. The parasitic loads for the boiler account for half of the GHG impact, while the other $50 \%$ is due to fuel production for harvesting and chipping operations. Transport distance considered in this study does not appear to be a key factor in the LCA analysis of the biomass plant. A 100 miles distance between the forests and the plant shows a contribution of $20 \%$ to the total GWP. However, when the biomass plant is compared with the incineration of MSW for electricity production (and then diverting waste to landfill), it is possible to notice that halving the fuel transport distance will reduce the impact by $10 \%$, resulting in a GWP which is still far from the almost zero impact of the MSW incineration plant.

The use of bottom ash as substituted fertiliser in landfarming activities would further reduce the environmental impact of the biomass plant. Bottom ash are produced in the biomass reactor and collected through the grate. They undergo a reprocessing stage which is mainly an inertization process, before being used as a potential source of potassium and phosphorous for landfarming. Pitman (2006) reported that 'for most forest sites, a single wood ash application per rotation could replace all the nutrients lost after whole-tree harvesting'. If used as fertilisers, bottom ash could represent a valuable by-product of biomass plant which could be sold to the market. For an environmental perspective, this could represent a reduction of the environmental impact of the bottom ash reprocessing, because avoided burdens could be accounted for the substitution of chemical fertiliser with wood ash. However, scant data is available, as very few studies have been published on the effect of wood ash use on land farming.

In this study, the GWP accounts for the uptake of the $\mathrm{CO}_{2}$ during forest regrowth crediting the $\mathrm{CO}_{2}$ emissions due to the burning of the biomass and therefore the emission factor for the biogenic $\mathrm{CO}_{2}$ is zero. This approach is valid for forest residue but it may not be applicable for other types of biomass. The type of residue assumed in this study is specific for the Heathrow energy centre biomass plant. As shown by Cherubini et al. (2011), bioenergy system with 
longer rotational periods can have a significant impact on the GWP. Moreover, land-use change can become relevant if the assumption on a sustainable growth of the biomass is no longer valid (Cherubini et al., 2014).

The forest residue left to decompose in the forest can contribute meaningfully to the GWP depending on the type of soil and weather conditions. On the other hand, the level of extraction of these residues can also alter the forest regrowth profile, because of the role of fertilizer compensation of the residues when left in the forest and lead to soil carbon permanently lost to the atmosphere (Cherubini et al., 2014). For the aim of this study, the decomposition of the forest residue left in the forest is considered negligible because of the different time frame of the baseline and reference scenarios. However, a further analysis should properly evaluate it for a full understanding of the environmental consequences of diverting forest residue from the forest for energy production.

\section{Conclusions}

This paper presents an attributional life cycle assessment of the Heathrow energy centre biomass plant. This is one of the largest biomass plants in the UK, producing $8 \mathrm{MWth}$ of heat and $2 \mathrm{MWe}$ of electricity for Heathrow Terminal 2 and 5. All the operations, from harvesting of the forest residue to boiler ash disposal, have been taken into account. The overall account of the GHG emissions of the biomass plant shows a negative balance (thus a positive effect for the environment) when avoided burdens due to electricity and thermal energy production from more conventional technologies are considered. Different results are obtained for the other impact categories considered. The organic Rankin cycle installed at Heathrow results in a lower environmental impact compared to an alternative steam turbine scenario, because of the higher efficiency of the ORC system. A comparison with other renewables (i.e. municipal solid waste) and non-renewable sources (i.e. natural gas and coal) for power production is carried out. While the biomass source results the best option for GHG emission savings, its impact can be higher for the categories related to ozone layer depletion due to ash disposal. Finally, further environmental impact reduction can be obtained if bottom ash is used for landfarming activities, although further research needs to be done to assess its feasibility.

\section{Acknowledgment}

We acknowledge Mark Lebus of LC Energy who kindly provided part of the primary data used for the analysis.

\section{References}


Amec. (2013). Greater London Authority Air Quality Support. Retrieved from https://www.london.gov.uk/sites/default/files/AMEC Emissions Standards Final Report 13103i1.pdf

Anandarajah G., Strachan. N., (2010). Interactions and implications of renewable and climate change Energy Policy Volume 38, Issue 11, November 2010, Pages 6724-6735.

Baumann, $\mathrm{H}$ and Tillman, A.M. 2004. The Hitch Hiker's Guide to LCA. Ed. Studentlitteratur AB. ISBN: 91-44-02364-2

BSI 2011. Specification for the Assessment of the Life Cycle Greenhouse Gas Emissions of Goods and Services (PAS 2050). British Standards Institution, London.

CCC, 2015. The Climate Change Act and UK regulations. Available at : $<$ https://www.theccc.org.uk/tackling-climate-change/the-legal-landscape/global-action-on-

climate-change/>

Cherubini F., Bird N., Cowie A., Jungmeier G., Schlamadinger B., Woess-Gallasch S. 2009. Energy- and greenhouse gas-based LCA of biofuel and bioenergy systems: key issues, ranges and recommendations, Resources, Conservation and Recycling 53: 434-447.

Cherubini, F., Peters, G.P., Berntsen, T., Stromman, A.H., Hertwich, E., 2011. CO2 emissions from biomass combustion for bioenergy: atmospheric decay and contribution to global warming, GCB Bioenergy 3: 413-426, doi: 10.1111/j.1757-1707.2011.01102.x

Christensen, T.H., Gentil, E., Boldrin, A., et al., 2009. C balance, carbon dioxide emissions and global warming potentials in LCA-modelling of waste management systems. Waste Management \& Research, 27(8), pp.707-15

Clift, R., Doig, A. and Finnveden, G., 2000. The Application Of Life Cycle Assessment To Integrated Solid Waste Management Part 1-Methodology. Institution of Chemical Engineers Trans IchemE, 78.

Clift, R. 2006. Sustainable Development and its Implications for Chemical Engineering. Chemical Engineering Science 61 (13), 4179-4187.

Clift, R. 2013. System Approaches: Life Cycle Assessment and Industrial Ecology, Chapter 17 in Pollutiion: Causes, Effects and Control, 5th Ed., ed. R.M.HarrisonRoyal Society of Chemistry, London.

DEFRA, 2008. Biomass Environmental Assessment Tool (BEAT2), available at: < http://www.biomassenergycentre.org.uk/portal/page?_pageid=74,153193\&_dad=portal\&_sch ema=PORTAL>

DEFRA, 2009. Municipal Waste Composition: Review of Municipal Waste Component Analyses - WR0119.

DEFRA, 2014. Statistics on waste managed by local authorities in England in 2013-2014. Available at: <https://www.gov.uk/government/uploads/system/uploads/attachment_data/file/375945/St 
atistics_Notice_Nov_2014_Final_3_.pdf>

DECC (Department of Energy and Climate Change), 2009. The UK Low Carbon Transition Plan. London, UK.

DECC, 2012. UK Bioenergy Strategy. Available at: $<$ https://www.gov.uk/government/uploads/system/uploads/attachment_data/file/48337/514 2-bioenergy-strategy-.pdf>

DECC, 2015. Policy paper: 2010 to 2015 government policy: greenhouse gas emissions. Appendix 4: carbon budgets.

Eastman. (2015a). Eastman to Expand Therminol ${ }^{\circledR}$ Heat Transfer Fluid Capacity. Retrieved May 14 , 2015, from http://www.eastman.com/Company/News_Center/2013/Pages/Eastman_to_Expand_THERMI NOL_Heat_Transfer_Fluid_Capacity.aspx

Eastman. (2015b). Therminol ${ }^{\circledR}$ 66: HEAT TRANSFER FLUID. Retrieved May 14, 2015, from http://www.therminol.com/products/Therminol-66

Ekvall, T., Finnveden, G. 2001. Allocation in ISO 14041 - a critical review, Journal of Cleaner Production 9: 197-208.

Eriksson, O., Finnveden, G., Ekvall T., Borkjolund A., 2007. Life cycle assessment of fuels for district heating: A comparison of waste incineration, biomass- and natural gas combustion. Energy Policy, 35(2), 1346-1362

Evangelisti, S., Lettieri, P., Borrello, D., Clift, R. (2013) Life Cycle Assessment of energy from waste via anaerobic digestion: a UK case study. Waste Management 34, Issue 1, Pages 226237, http://dx.doi.org/10.1016/j.wasman.2013.09.013.

Evangelisti, S., Tagliaferri, C., Clift, R., Lettieri, P., Taylor, R., \& Chapman, C. (2015). Life cycle assessment of conventional and two-stage advanced energy-from-waste technologies for municipal solid waste treatment. Journal of Cleaner Production, 100, 212-223. doi:10.1016/j.jclepro.2015.03.062

Fergani, Z., Touil, D., \& Morosuk, T. (2016). Multi-criteria exergy based optimization of an Organic Rankine Cycle for waste heat recovery in the cement industry. Energy Conversion and Management, 112, 81-90. https://doi.org/10.1016/J.ENCONMAN.2015.12.083

Fruergaard T., Astrup, T., Ekvall, T., 2009, Energy use and recovery in waste management and implications for accounting of greenhouse gases and global warming contributions. Waste Management and Research, 27 (8), 724-737.

Guest, G., Cherubini, F., \& Strømman, A. H. (2013). Global Warming Potential of Carbon Dioxide Emissions from Biomass Stored in the Anthroposphere and Used for Bioenergy at End of Life. Journal of Industrial Ecology, 17(1), 20-30. doi:10.1111/j.1530-9290.2012.00507.x

Guinée J.B.(final editor), M. Gorrée, R. Heijungs, G. Huppes, R. Kleijn, L. van Oers, A. Wegener Sleeswijk - S. Suh - H. A. Udo de Haes, H. de Bruijn - R. van Duin - M.A.J. Huijbregts, 2001. Life Cycle Assessment An operational guide to the ISO standards, Volume 1, 2 en 3. Centre of 
Environmental Science Leiden University, Leiden, the Netherlands

Hassoun, A., \& Dincer, I. (2015). Analysis and performance assessment of a multigenerational system powered by Organic Rankine Cycle for a net zero energy house. Applied Thermal Engineering, 76, 25-36. https://doi.org/10.1016/J.APPLTHERMALENG.2014.11.017

Hauschild, M \& H. Wenzel, 1998: Environmental Assessment of products. Volume 2: Scientific background. Chapman \& Hall, London.

Heathrow energy centre, 2014. Personal communications.

Heathrow, 2015. The Heathrow energy centre biomass plant. Official website available at: http://www.heathrowairport.com

Heijungs, R., Guinée, J.B., 2007. Allocation and "what-if" scenarios in life cycle assessment of waste management systems. Waste management (New York, N.Y.) 27, 997-1005

Imran, M., Park, B.-S., Kim, H.-J., Lee, D.-H., \& Usman, M. (2015). Economic assessment of greenhouse gas reduction through low-grade waste heat recovery using organic Rankine cycle (ORC). Journal of Mechanical Science and Technology, 29(2), 835-843. https://doi.org/10.1007/s12206-015-0147-5

ILCD 2010. European Commission - Joint Research Centre - Institute for Environment and Sustainability: International Reference Life Cycle Data System (ILCD) Handbook - General guide for Life Cycle Assessment - Detailed guidance. First edition March 2010. EUR 24708 EN. Luxembourg. Publications Office of the European Union.

ILCD, 2011. European Commission-Joint Research Centre - Institute for Environment and Sustainability: International Reference Life Cycle Data System (ILCD) HandbookRecommendations for Life Cycle Impact Assessment in the European context. First edition November 2011. EUR 24571 EN. Luxemburg. Publications Office of the European Union.

IPCC, 2007: Climate Change 2007: The Physical Science Basis. Contribution of Working Group I to the Fourth Assessment. Report of the Intergovernmental Panel on Climate Change. [Solomon, S., D. Qin, M. Manning, Z. Chen, M. Marquis, K.B. Averyt, M. Tignor and H.L. Miller (eds.)]. Cambridge University Press, Cambridge, United Kingdom and New York, NY, USA, 996 pp.

ISO, 2006a. ISO 14040 Environmental management - life cycle assessment - principles and framework. Geneva: ISO

ISO, 2006b. ISO 14044 Environmental management -- Life cycle assessment -- Requirements and guidelines. Geneva: ISO

Jenkin, M.E. \& G.D. Hayman, 1999: Photochemical ozone creation potentials for oxygenated volatile organic compounds: sensitivity to variations in kinetic and mechanistic parameters. Atmospheric Environment 33: 1775-1293.

Kerr, G., and HAufe, J, 2011. Thinning practice. A silvicultural guide, Version 1.0. Forestry Commission. Available at

http://www.forestry.gov.uk/pdf/Silviculture Thinning Guide v1 Jan2011.pdf/\$FFLE/Silvicultur e Thinning Guide v1 Jan2011.pdf 
Kretschmer, B., Watkins, E., Baldock, D., Allen, B., Keenleyside, C., Tucker, G. 2011. Securing biomass for energy - developing an environmentally responsible industry for the UK now and into the future, report of the Institute for European environmental policy. Available at: < http://www.ieep.eu/assets/856/IEEP_UK_responsible_bioenergy.pdf>

LATVIA AND THE EUROPEAN COMMISSION, 2015. SUBMISSION BY LATVIA AND THE EUROPEAN COMMISSION ON BEHALF OF THE EUROPEAN UNION AND ITS MEMBER STATES.

Available

at

http://www4.unfccc.int/submissions/INDC/Published\%20Documents/Latvia/1/LV-03-

06-EU\%20INDC.pdf

Lecompte, S., Huisseune, H., van den Broek, M., Vanslambrouck, B., \& De Paepe, M. (2015). Review of organic Rankine cycle (ORC) architectures for waste heat recovery. Renewable and Sustainable Energy Reviews, 47, 448-461. https://doi.org/10.1016/J.RSER.2015.03.089

LC Energy, 2015. Official website: http://Icenergy.co.uk/. Last access: 10/07/2015

Manfredi, D. Tonini, T.H. Christensen, 2011. Environmental assessment of different management options for individual waste fractions by means of life-cycle assessment modelling Resources, Conservation and Recycling, 55 (11) (2011), pp. 995-1004 http://dx.doi.org/10.1016/j.resconrec.2011.05.009

Manfredi, S., Pant, R. 2012. Improving the environmental performance of bio-waste management with life cycle thinking (LCT) and life cycle assessment (LCA). The International Journal of Life Cycle Assessment, (Ec 2010).

Meent \& M. Hauschild (2008). Usetox - the UNEP-SETAC toxicity model: recommended characterisation factors for human toxicity and fresh water ecotoxicity in life cycle impact assessment. Int J LCA (2008) 13:532-546

Morgani Sindall, 2015. Heathrow energy infrastructure project. Official website available at: <http://construction.morgansindall.com/case-study/heathrow-energy-infrastructure-project> National Grid, 2014. UK Future Energy Scenarios. Available at: <http://www2.nationalgrid.com/uk/industry-information/future-of-energy/fes/Documents/> Obernberger, I., Thonhofer, P., \& Reisenhofer, E. (2002). Description and evaluation of the new $1000 \mathrm{kWel}$ Organic Rankine Cycle process integrated in the biomass CHP plant in Lienz, Austria.

Euroheat \& Power, 10/2002. Retrieved from http://www.turboden.eu/en/public/downloads/report_on_lienz_plant.pdf

OECD (1991), Estimation of greenhouse gas emissions and sinks, final report from OECD experts meeting, 18-21 February, 1991, OECD, Paris.

Rosenbaum R.K., T.M. Bachmann, L.Swirsky Gold, M.A.J. Huijbregts, O. Jolliet, R. Juraske, A. Koehler, H.F. Larsen, M. MacLeod, M. Margni, T.E. McKone, J. Payet, M. Schumacher, D. van de Sedpho, S., Sampattagul, S., Chaiyat, N., \& Gheewala, S. H. (2017). Conventional and exergetic life cycle assessment of organic rankine cycle implementation to municipal waste management: the case study of Mae Hong Son (Thailand). The International Journal of 
Life Cycle Assessment, 22(11), 1773-1784. https://doi.org/10.1007/s11367-016-1216-4

Saiyasitpanich, P., Keener, T. C., Khang, S.-J., \& Lu, M. (2007). Removal of diesel particulate matter (DPM) in a tubular wet electrostatic precipitator. Journal of Electrostatics, 65(10-11), 618-624. doi:10.1016/j.elstat.2007.01.005

Swiss Centre for Life Cycle inventories. (2011). Ecoinvent: the life cycle inventory data, Version

2.1. Swiss Centre for Life Cycle Inventories, Duebendorf.

Sununta, N., Sedpho, S., Gheewala, S. H., \& Sampattagul, S. (2017). Life cycle greenhouse gas evaluation of organic rankine cycle using refuse-derived fuel from municipal solid waste. Journal of Renewable and Sustainable Energy, 9(5), 54901. https://doi.org/10.1063/1.5006209

Tillman, A.-M., Ekvall, T., Baumann, H., \& Rydberg, T. (1994). Choice of system boundaries in life cycle assessment. Journal of Cleaner Production, 2, 21-29.

Thinkstep. (2015). GaBi 6 software-system and databases for life cycle engineering. Stuttgart, Echterdingen (see www.pe-europe.com).

Turboden. (2015). Turboden: References - Search. Retrieved May 14, 2015, from http://www.turboden.eu/en/references/references.php

Turboden. (2104). Data Sheet- Turboden combined heat \& power (CHP) units with splitstypical sizes and performances. Retrieved May 14, 2015, from http://www.turboden.eu/en/public/downloads/CHP con Split.pdf

UK Government, 2009. The UK Renewable Energy Strategy. Available at: <http://www.biomassenergycentre.org.uk/pls/portal/docs/PAGE/RESOURCES/REF_LIB_RES/P

UBLICATIONS/THEUKRENEWABLEENERGYSTRATEGY2009.PDF>

US EPA (Environmental Protection Agency), 2011. Accounting Framework from Biogenic CO2 emissions from Stationary Sources.

Yang, M.-H., \& Yeh, R.-H. (2015). Thermodynamic and economic performances optimization of an organic Rankine cycle system utilizing exhaust gas of a large marine diesel engine. Applied Energy, 149, 1-12. https://doi.org/10.1016/J.APENERGY.2015.03.083

Whittaker, C., Mortimer, N., Murphy, R. and Matthews, R., 2011. Energy and greenhouse gas balance of the use of forest residues for bioenergy production in the UK. Biomass and Bioenergy, 35 (11), pp. 29-45.

WMO (World Meteorological Organisation), 2003: Scientific assessment of ozone depletion: 2003. Global Ozone Research and Monitoring Project - Report no. XX. Geneva. 
